\title{
Labor Warranty Policy Implementation in the North Konawe Regency of Southeast Sulawesi Indonesia
}

\author{
Sri Suwitri ${ }^{1}$, Tri Yuniningsih $^{1}$, Moch. Mustam ${ }^{1}$ \\ ${ }^{1}$ Public Administration Department, Faculty of Social and Political Science, Universitas Diponegoro, Semarang - Indonesia
}

\begin{abstract}
JAMPERSAL aims to eliminate barriers to pregnant women for financial gain, including labor inspection guarantee pregnancy, parturition, Ministry and Service of the Newborn. Problems faced are: many societies that don't utilize JAMPERSAL, uneven first level services, the limited information, process claims, limitations of means and health facilities, and overlapping regulations. Research objectives are: (1) analyze how implementation program of JAMPERSAL, (2) analyze the precision of the policy implementation of JAMPERSAL, and (3) identify the factors restricting the driving policy implementation and of JAMPERSAL. This study type's is descriptive with a qualitative approach, data collection with interviews, observation and FGD. The technique of determination of the informants is Purposive. data analysis with the reduction, the presentation, and verification. JAMPERSAL policy in North Konawe Regency has been conducted using appropriate Regulation there is, seen from the aspect of accuracy. Seen from the aspect of the precision of the process are still not aware that completion of the executor and the public in implementing policies. As for the factors that support is the communication, while restricting factor was resources, attitudes/disposition, and bureaucratic structure. The recommendations presented: recommendations presented was so that the Government in making the rules clearer and does not cause misinterpretation and socialization continued support to communities in remote areas so that they will understand the policy.
\end{abstract}

Keywords: Jampersal; Implementation of The Policy; BPJS.

\section{Introduction}

In the North Konawe of Southeast Sulawesi Province, cases of maternal mortality in the past three years are still relatively high. In the report in 2012 there are two cases of maternal death or equivalent to 265 maternal deaths/100,000 live births, far above the target MDGs. Likewise in a row in 2013 and 2014 are reported there were as many as three and two cases of maternal death giving birth. Problems faced: many societies that do not utilize JAMPERSAL, uneven first level services, keterbatan information, process claims, limitations of means and health facilities, and overlapping regulations. The purpose of this research is: (1) analyze how implementation program of JAMPERSAL in North Konawe Regency Southeast Sulawesi, (2) analyze the precision of the policy implementation of JAMPERSAL, and (3) identify factors driving and restricting the policy implementation of JAMPERSAL. Research methods, the study type are descriptive qualitative approach, data collection with interviews, observation and FGD. The technique of informant determination is Purposive. Data analysis is done by reduction, the presentation, and verification. The focus is the policy implementation of Jampersal, the focus in North Konawe Regency Southeast Sulawesi. Primary data retrieved from the specified resource are purposive, i.e. the head of the Health Office, the PKK, midwives, Coordinator, Head of Health Centers, Health Workers in Clinics, Herbalists, Nurses, Hospitals and Provider of the BPJS. In addition to the prescribed patient/Community are accidental in a hospital or clinic. While secondary data obtained from libraries, electronic media, and Internet, as well as journals. Data analysis was performed by means of data collection, data verification, and conclusion. For data validation is with the triangulation sources.

Infant mortality rate are closely related to the environment. Unhealthy environment such as dirty and polluted work environment lead to threatened pregnant workers. Hence, the labor warranty (JAMPERSAL) need to be implemented well.

\section{Methodology}

This study type's is descriptive with a qualitative approach, data collection with interviews, observation and FGD. The technique of determination of the informants is Purposive. data analysis with the reduction, the presentation, and verification. JAMPERSAL policy in North Konawe Regency has been conducted using appropriate Regulation there is, seen from the aspect of accuracy. 


\section{Discussion}

In analyzing a problem required supporting theory and considered relevant to be able to help solving a problem. This research is using the Implementation theory of George Edward III and Riant Nugroho. Riant Nugroho communicated that: "the effectiveness of the policy implementation can be seen from the "five" factors, namely: first, the policy appropriateness, second, the precision of the executor, third, the target precision, fourth, environment accuracy, and fifth is the precision of the process [1]. To find out the factors that inhibit or encourage a policy implementation used the theory of George Edward III, those are: communication, resources, attitudes or dispositions and bureaucratic structure [2]. As for the observed phenomenon will see the implementation of policy Jampersal aspects of the precision that is the precision of the process, with a view of implementing preparedness in carrying out the policy and the readiness of the Community/target group in the running the policy. As well as driving factor and the factor restricting policy.

JAMPERSAL policy in North Konawe Regency bases on Constitutional Law No. 36 in 2009 about health and the regulation of the Ministryof Health. No 43 in 2016 about SPM of health sector. Jampersal Policy in North Konawe ever implemented in 2012 then vacum because is overlapping with the Jamkesmas, now healthy and Card BPJS. In 2017 is going back with KIS. Thus it is evident that the Government has had a strong commitment to realize the social welfare for all the people. The implementation of Jampersal program in North Konawe Regency follow the principles in the regulation that exists and this is an attempt of keeping continuity of healthcare for the poor or not capable. There is no reason for people who are less able to there is no fee to get service of labor normally. So that maternal mortality and infant mortality can be avoided. Guarantee management of Labor in every level of Government (Central, Provincial, and District/City) into a single entity with management of Operational Assistance and Health Jamkesmas (BOK).

For the management of membership Jampersal, the membership of the program is an extension Jamkesmas who follow the membership of governance and management Jamkesmas, however with specificity in terms of the determination of the participants. Then Jampersal is the entire program targets that do not yet have Jampersal. Participants can take advantage of services across the network of health care facilities at the first level and advanced level (Hospital) in class III has the agreement of cooperation (MCC) with Team Manager Jamkesmas and BOK/City. The implementation of Jampersal service refers to a service standard maternal and child health $(\mathrm{MCH})$, organized by the principle of portability and structured services tiered based on the reference. Package delivery service for first-level health is facilitated Government (and its network of clinics) funded based on the proposed POA clinic. While the Ministry of labor package in first level paid by private health facilities the mechanism of the claim. The claims are based on the delivery place (site area) Ministry of labor performed.

The process accuracy is the policy that has been created in accordance with the process in the policy implementation public so that implementers understand the tasks and policies of the target group received the policy [1]. As for the indicators to judge it is by seeing how implementing preparedness in carrying out policies and How the readiness of the community in carrying out the policy.

Each policy is made to answer the problems that occurred in the community of such policies with the sake that the problem can be solved. To be able to solve existing problems in implementing preparedness required target groups in running this policy. From the results of fieldwork can be known that readiness of the executor will be important to help Guarantee delivery for the community in particular target group is very helpful especially the target group of poor families or less capable. If the implementer has known then it is with every form of readiness to carry out the policy guarantee of labor. The form of the readiness of the executor in carrying out policies can be described in the form of juknis where the Labor Ministry done in a structured and stratified on the basis of reference, where the scope of services Jampersal Services include: the first level of labor, the Ministry of labor advanced level, the guarantee benefit Package delivery, funding, Jampersal and organizing. The findings in the field still occurs the implementing regulations in understanding the unpreparedness that exists (Juknis), where the implementers have felt the terms specified for getting service Jampersal is very easy, but the standard and the purpose of the Jampersal program set forth in the applicable Juknis considered still a blur by implementing programs in the field. Many view the pros and cons that appear related poor enforcement of rules used in the technical instructions. It's what makes the implementation on the ground is not well achieved.

In running the policy role of the community, as the target groups that receive its benefits. Because of the readiness of the community needed to participate in the national program course of a policy so that the goal of the policy can be achieved. So to know the readiness of the community in carrying out the policy of Jampersal with a view of understanding the Community target groups against the policies of Jampersal. From the results of field research community are understanding about policy Jampersal over this still. It is depending on the socio-economic condition of the community. Socio-economic conditions turned out to affect the mindset of the community in understanding the policy. Besides the geographical condition of North Konawe still-remote also affects the understanding of the people about the policy of Jampersal, where the Jampersal Help can only be claimed if the services performed in the hospital or clinic. Whereas if they live in areas that are a bit far from hospitals or community health centers prefer to shaman babies even without assistance funds from the Jampersal. Yet the completion of the Community target groups in carrying out this policy 
because as long as this society still more believe in shamans babies from health workers or midwives in the villages. When baby shaman with the Ministry received the society for longer time, thorough, painstaking, patient and care by baby shaman usually until 40 days while the village midwife if with more or less the only 7 (seven) days and only when required course. Thus it can be concluded that the public's own goal proved less ready/group implement policies about Jampersal.

From the results of research field found factors that hinder or support in the policy implementation. Communication, the communication factor in the overall implementation of the policy of Jampersal in North Konawe Southeast Sulawesi during this run either program, the transmission between the holder and the policy executor is already agree. Socialization has been running well, consistency between policy instruments complement each other as well as with the clarity of the objectives and implementation of Jampersal program. Resources, owned by the Department of Health is currently still very inadequate, most of them just want to work in the cities and did not want to be placed in remote areas. In addition the people who qualify for selection must be an employee of the profesioanal. The limitation of the number of health facilities such as the limited number of Poskesdes could be one of the causes of the low coverage of the Jampersal program, although delivery can also be made at home the village midwife. To the limitations of the tools also constraints because most of the village midwife was given only a midwife kit by health services, while other such completeness bed specifically for maternity, cocor ducks and was not given oxygen tubes. Disposition or attitude of the Executor, in this attitude in addressing issues of policy apparatus still using classical ways in policy implementing, meaning that it still be waiting for a command or without the initiative. Besides transparency are still at the level of implementing managerial level while still lacking awareness. The findings also noted that field officers and manufacturers in the process of implementation of the policy have not shown an attitude of Jampersal an optimal support. Bureaucratic structure, implementation policy urgently needs the full support of the Government. In addition it also upgraded oversight needs to be against the hospital in Jampersal service. Given the still many people who do not have the BPJS and many transmingran communities so that the hospital itself is experiencing difficulty in the granting of Ministry Jampersal. Findings related to this field are administrative violations in management of Jampersal i.e. borrowing Card Healthy neighbors, and confusion in the hospital doing the claims because the patient is the trans-community, where they are when a problem occur the responsibility of Social Service.

\section{Conclusion}

The conclusions that can be delivered from the results of this study are: (1) policy implementation of Delivery
Assurance (Jampersal) in North Konawe Regency Southeast Sulawesi have been conducted according to existing regulations, until the completion of this research society still use the BPJS. Given the start of June will be done soaialisasi on the use of Cards Healthy Indonesia funded by the GRANT. (2) Seen from the aspect of the precision of the process are still not aware that completion of the executor and the public in implementing policies. (3) As for the factors that support is the communication, while restricting factor was resources, attitudes/disposition, and bureaucratic structure. The recommendation is submitted so that the Government in making the rules clearer and does not give rise to misinterpretation in the content policy and socialization which is constantly done to communities in remote areas so that they will understand the policy was launched.

\section{References}

1. R. Nugroho, Kebijakan Publik, Formulasi, Implementasi, dan Evaluasi, Elex Media Komputindo, Jakarta (2011).

2. C. George Edwards III, Implementing Public Policy, Congressional Quarterly Inc, Washington D. C (1980).

3. L. Agustino, Kebijakan Publik, Alfabeta, Bandung (2006).

4. B. Bungin, Penelitian Kualitatif, Predana Media Group, Jakarta (2010).

5. Emzir, Metodologi Penelitian Kualitatif Analisis Data, Rajawali Pos, Jakarta (2010).

6. I. Islamy, Implementasi Kebijakan, Bumi Aksara, Jakarta (1994).

7. M. Nazir, Metodologi Penelitian, Ghala Ind, Jakarta (1988).

8. Sugiyono, Metode Penelitian Administrasi, Alfabeta, Bandung (2010).

9. D. I. Jaya, Implementasi Program Jampersal di PUSKESMAS Ngesrep kota Semarang ditinjau dari Aspek Kepesertaan, Skripsi FISIP-UNDIP (2013).

10. Hariyanto, Analisis Jaminan Kesehatan Masyarakat (Jamkesmas) dalam Menjamin Kesehatan Masyarakat, yang disahkan oleh SK Menkes No.125 Tahun 2008, Jakarta (2009).

11. Khotib, Implementasi Kebijakan Jaminan Kesehatan Masyarakat (Jamkesmas) Stusy Pada Dinas Kesehatan Kabupaten Pasuruhan, Pascasarjana, Bandung (2009).

12. Santosa, Amir, Analisis Kebijakan Publik, Masalah dan Pendekatan, J. I. P. No. 3, Gramedia, Jakarta (1998). 